\title{
A critique of the Cornell Net Carbohydrate and Protein System with emphasis on dairy cattle. 3 . The requirements model
}

\author{
The late G. Alderman \\ revised by J. France and E. Kebreab
}

The University of Reading, Department of Agriculture

Earley Gate, Reading RG6 2AT, UK

(Received 11 April 2000; revised version 1 March 2001; accepted 7 August 2001)

\begin{abstract}
The Cornell Net Carbohydrate and Protein System (CNCPS) adopts energy requirements as Mcals of metabolizable energy (ME) largely as NRC (1988), which are to be used with feed ME values as measured at the maintenance level of feeding. However, the model inserts calculated production level ME values into these NRC standards, equivalent to an upwards correction of about $5 \%$ to the estimates of ME requirements adopted. The energy accounting of the model is therefore flawed. The maintenance requirement of all breeds of dairy cattle, other than Holstein, are increased by a factor of 1.2 , based on work with beef suckler cows. The efficiency of ME use for milk synthesis is also raised to a constant 0.65 from the normal range of 0.62 to 0.64 specified in NRC (1988). The net effect on the adopted ME requirements at milk yields of $30 \mathrm{~kg} / \mathrm{d}$ is small, but both slope and intercept of the equation differ from NRC (1988). The model includes no effect of diet amount and composition upon nutrient partitioning between milk and body. Neither is there any effect of diet composition upon predicted milk composition, which is either an input to the model or a function of day of lactation. The body composition of growing heifers and cows up to four years of age is predicted by a function which has a maximum body fat content of $22.5 \%$, only 0.86 of the total body fat recorded in recent body composition measurements in Friesian dairy cows. Associated estimates of maximum mobilizable body fat are one half or more below recent measurements with dairy cows. The handling of energy losses and gains during lactation uses condition score as a measure and ignores liveweight change. This is also based on research with suckler beef cows, and shown to over-estimate the energy equivalent of a unit change in condition score of Holstein dairy cows. Prediction of dry matter intakes is closer to actual than other prediction functions available and the lag in intake in early lactation is also accommodated well. The consequence of using mismatched energy requirements (as ME) is that the model predicts significantly lower milk yields at zero energy balance (or lower energy
\end{abstract}


balances if milk yield is given) compared to both NRC (1988) and AFRC (1993). However, field tests of the model have shown that predicted milk yields are closer to actual than those from other models.

KEY WORDS: dairy cows, lactation, energy, protein, amino acids, requirement, intake

\section{INTRODUCTION}

Preceding papers (Alderman et al., $200 \mathrm{la}, \mathrm{b}$ ) reviewed the rumen and post-rumen supply sub-models of the CNCPS. This paper deals with the requirements sub-model and uses the same terminology and symbols as used in the original set of papers defining the model (Fox et al., 1992; Russell ct al., 1992; Sniffen et al., 1992; O’Connor et al., 1993).

\section{REQUIREMENTS FOR ENERGY AND PROTEIN}

The CNCPS is claimed to predict nutrient requirements and animal performance over wide variations in type of cattle (growing and finishing cattle, suckler and dairy cows), feed, management and environmental conditions, largely based on the NRC publications (NRC, 1984, 1985, 1988, 1996). This review only deals with the nutrient requirements of dairy cattle as used in the CNCPS, which are largely as NRC (1985) for metabolizable protein and NRC (1978; 1988) for metabolizable energy and net energy for lactation. Additional correction factors are introduced, particularly in the maintenance and environmental aspects of energy requirements.

Effects of liveweight, breed and age

Energy. The effects of liveweight per se on energy requirements are expressed on a metabolic liveweight basis $\left(\mathrm{W}^{0.75}\right)$. Thus the basic maintenance requirement is as NRC (1988): $133 \mathrm{kcal} \mathrm{ME} / \mathrm{kg} \mathrm{W}^{0.75}\left(=0.556 \mathrm{MJ} \mathrm{ME} / \mathrm{kg} \mathrm{W}^{0.75}\right)$ which incorporates a $10 \%$ activity allowance. This maintenance estimate is stated by $\mathrm{NRC}$ (1988) to have been adjusted to match feed/diet ME values listed in the associated Feed Composition Table 7.1 which are annotated as having been determined at the maintenance level of feeding. The maintenance energy requirement is similar to that implied in AFRC (1993) when calculated for a $600 \mathrm{~kg}$ cow under stall feeding conditions, i.e. $0.537 \mathrm{MJ} \mathrm{ME} / \mathrm{kg} \mathrm{W}^{0.75}$, also expressed at the maintenance level of feeding. The NRC (1988) cstimate of maintenance energy requirement is only applied in the CNCPS v.3.0 to pure bred Holstein dairy cows, since Appendix Table 6 of Fox et al. (1992) adjusts the maintenance requirements for lactating 
dairy cows upwards by a factor of 1.2 for pure bred Ayrshire, Brown Swiss, Fricsian, Guernsey and Jersey dairy cows, and to all cross bred cows, such as HolsteinFriesian. This correction is based on a literature review by George (1984), which dealt with beef suckler cows. Subsequently, Yan et al. (1997) have suggested that a factor of 1.4 times the $\mathrm{ARC}$ (1980) ME requirement for maintenance is needed for Holstein-Friesian cows on high grass silage diets. Maintenance requirements (as Mcal of ME) are also adjusted for the energy cost of urea excretion, based on the calculation of excess rumen degradable protein (RDP), as NRC (1988), although this cost is included in estimates of maintenance energy requirements. Complex adjustments for air temperature, wind speed, humidity and amount of mud on the animal are incorporated, many of which do not apply to housed dairy cattle.

Protein. The metabolizable protein (MP) requirements for maintenance are the sum of scurf protein (SPA), urinary protein (UPA), and metabolic faecal protein (FPN), where UPA and FPN are as NRC (1985):

$$
\begin{aligned}
& \mathrm{UPA}=2.75 \mathrm{~W}^{0.5} / 0.67 \text { (c.f. ARC, 1984: }=0.35 \mathrm{~W}^{0.75} / 0.85 \text { ) } \\
& \mathrm{FPN}=0.09 \mathrm{IDM}
\end{aligned}
$$

where

$\mathrm{W}$ is liveweight, $\mathrm{kg}$

IDM is total faecal DM (dry matter), $\mathrm{kg} / \mathrm{d}$.

As published in Fox et al. (1992), the equations for SPA and UPA are reversed compared to NRC (1985) and NRC (1996). For a $600 \mathrm{~kg}$ cow, the UPA requirement of $100 \mathrm{~g} \mathrm{~N} / \mathrm{d}$ is twice that of ARC (1984) and AFRC (1992), which would appear to merit further enquiry. AFRC (1992) recognised FPN as a component of its maintenance term "basal endogenous N" (BEN), based on the DM intake (DMI) for maintenance, but not for the whole dict as in NRC $(1985 ; 1996)$ and the CNCPS, arguing that the $\mathrm{N}$ losses involved were taken into account in their estimated efficiency of MP utilization for milk synthesis $\left(\mathrm{k}_{\mathrm{n} l}\right)$. As the value for $\mathrm{k}_{\mathrm{n} 1}$ adopted is 0.68 , which is higher than 0.65 adopted by NRC (1985), this may be questioned. Maintenance requirements for MP in NRC (1985) and the CNCPS are the sum of these three components:

where

$$
\mathrm{MP}_{\mathrm{m}} \text { or } \mathrm{XP}=\mathrm{SPA}+\mathrm{UPA}+\mathrm{FPN}
$$

$\mathrm{MP}_{\mathrm{n}}$ or $\mathrm{XP}$ is metabolizable protein in $\mathrm{g} / \mathrm{d}$ required for maintenance.

Ruminant protein requirement systems that have a term for FPN included are known to predict much higher total MP requirements (Jones et al., 1996). For a DM intake of $20 \mathrm{~kg} / \mathrm{d}$ and dry matter digestibility of $0.75(5 \mathrm{~kg} / \mathrm{d}$ of IDM), the NRC (1985) equation gives $450 \mathrm{~g}$ MP to be added to the MP requirement, elevat- 
ing the "maintenance" MP requirements about $400 \mathrm{~g} / \mathrm{d}$ above AFRC (1993) tabulated values. The FPN for the DMI above that needed for maintenance must surely be regarded as a cost that should be allocated to milk or tissue synthesis, not maintenance.

Milk

Energy. Lactation requirements for energy in NRC (1988), largely adopted in the CNCPS, are affected by breed inasmuch as the mean milk composition for fat and protein are affected by breed, but plane of nutrition is without effect upon energy requirement, which is stated as per $\mathrm{kg}$ milk at the maintenance level of feeding for TDN (total digestible nutrients), DE (digestible energy) and ME requirements and at three times maintenance for net energy for lactation (NEL) requirements. Efficiencies of utilization of ME for lactation in the CNCPS are set at a constant either 0.65 or 0.644 , the latter figure being attributed to Moe et al. (1972). These coefficients can be compared to those in NRC (1988) i.e. 0.62 to 0.64 and AFRC (1993) of 0.61 to 0.65 for ME utilization for milk synthesis.

Although the CNCPS v.3.0 clearly relies upon NRC (1988) ME requirements stated to be used with feed ME values determined at maintenance, the calculation of ME supply in the model produces production level TDN values (aTDN), $\mathrm{DE}$ and ME values, as shown by Alderman et al. (2001b). At a typical feeding level of three times maintenance, aTDN values are $8 \%$ lower than the tabulated maintenance TDN values (bTDN) in NRC (1988), since a decline in digestibility of $4 \%$ per unit increase in feeding level (L) above maintenance is specified in $\mathrm{NRC}$ (1988). The decline in estimated ME intake is only $2 \%$ per unit increase in feeding level, due to compensating reductions in methane losses at higher levels of feeding. For a typical dairy cow giving $30 \mathrm{~kg}$ milk/d, whose ME requirement is c. $220 \mathrm{MJ} \mathrm{ME} / \mathrm{d},(\mathrm{L}=3.4)$ this reduction in $\mathrm{ME}$ supply is about $10 \mathrm{MJ} / \mathrm{d}$, equivalent to a reduction in predicted milk yield of about $2 \mathrm{~kg} / \mathrm{d}$. There is therefore a theoretical error in the energy model in CNCPS v.3.0, since the first law of thermodynamics (energy conservation) is not being observed. It also explains in part why the CNCPS v.3.0 model predicts significantly lower milk yields (c. $5 \mathrm{~kg} / \mathrm{d}$ ) than AFRC (1993), as found by Mansbridge et al. (1999). The remaining difference in milk yield was due to the 1.2 times higher maintenance $\mathrm{ME}$ requirement (equivalent to a further $12 \mathrm{MJ} / \mathrm{d}$, or $2.4 \mathrm{~kg}$ milk/d) allocated to the Holstein-Friesian cows used in the latter study.

Protein. Lactation requirements for protein are similarly affected by breed of cow and stage of lactation, but plane of nutrition is without effect upon protein requirements, which are stated as per kg milk, as in all other protein models. Efficiencies of utilization of MP for lactation are set at a constant 0.65 , lower than the AFRC (1992) figure of 0.68 for MP, with no allowance for FPN included. 
Growth to mature body weight in lactating heifers and dairy cows

The CNCPS identifies the need for, and the scale of body growth in immature but lactating dairy cattle, separately from the replenishment of body reserves. A family of 11 equations is given in Appendix Table 9 of Fox et al. (1992), quoting the modifications of Fox et al. (1988) to earlier published work on Gompertz growth curves as applied to beef and dairy cattle. The estimates require inputs of mature body weight, frame size (as defined in Appendix Table 1 of Fox et al., 1992), and cow age in days. Estimates of expected daily growth rate $(\mathrm{g} / \mathrm{d})$, total empty body fat (AF), protein content of gains (PB), metabolizable energy $(\mathrm{Mcal} / \mathrm{d})$ and metabolizable protein $(\mathrm{g} / \mathrm{d})$ required, are supplied by these equations:

$$
\mathrm{AF}(\%)=22.5\left[1-\exp \left(-0.00536^{*} \text { age in } \mathrm{d}\right)\right]
$$

This equation gives low values for animals under 1 year of age $[7-20 \%$ fat in empty body weight (EBW)], reaches $22.1 \%$ at 2 years, and a maximum of $22.5 \%$ by about 3 years of age. Thus for a 4 year old dairy cow weighing $600 \mathrm{~kg}(531 \mathrm{~kg}$ EBW), the approach of Fox et al. (1992) gives a value of $119 \mathrm{~kg}$ fat. Gibbs and Ivings (1993), working with Friesian cows, derived relationships between total body fat, energy value, condition score (CS) and cow liveweight as follows:

$$
\begin{aligned}
& \text { Fat }(\mathrm{kg})=41.86 \mathrm{CS}+0.292 \mathrm{~W}-162.5 \\
& \text { Energy }(\mathrm{MJ} / \mathrm{kg})=1,615 \mathrm{CS}+13.88 \mathrm{~W}-6,750
\end{aligned}
$$

Equation (5) gives a value of $138 \mathrm{~kg}$ total body fat for a $600 \mathrm{~kg}$ cow in condition score 3,20 kg above the estimate from Fox et al. (1992), equation (4).

The protein content of empty body gains (EBG) in the CNCPS is given by:

$$
\mathrm{PB}(\% \mathrm{EBG})=0.7995\{100-[(76.3-0.973 \mathrm{AF} \%)+\mathrm{AF} \%]\}
$$

Equation (7) does not make sense, with AF\% appearing twice.

Figure I shows the results of applying the equation sequence of Fox et al. (1992) to a Holstein dairy cow of $700 \mathrm{~kg}$ mature body weight (frame size 10) from two years $(700 \mathrm{~d})$ to about five years of age $(1848 \mathrm{~d})$, when mature weight is predicted to be reached. The calculated energy value of the gains $(\mathrm{EVg})$ is also plotted in Figure 1.

Growth is predicted to be $570 \mathrm{~g} / \mathrm{d}$ at 700 days of age, falling to $120 \mathrm{~g} / \mathrm{d}$ by $1100 \mathrm{~d}$ ( 3 years). The protein content of these gains is constant at $18.5 \%$, giving MP requirements of $187 \mathrm{~g} / \mathrm{d}$ falling to $15 \mathrm{~g} / \mathrm{d}$ at 3 years of age. The ME requirement for gains are calculated using net energy for gains $\left(\mathrm{NE}_{\mathrm{g}}\right)$, as NRC (1984), but using a low efficiency of ME utilization of only $40 \%$, compared to ARC (1980), which for a typical dairy cow diet $(q=0.6)$ gives an efficiency of $50 \%$. 


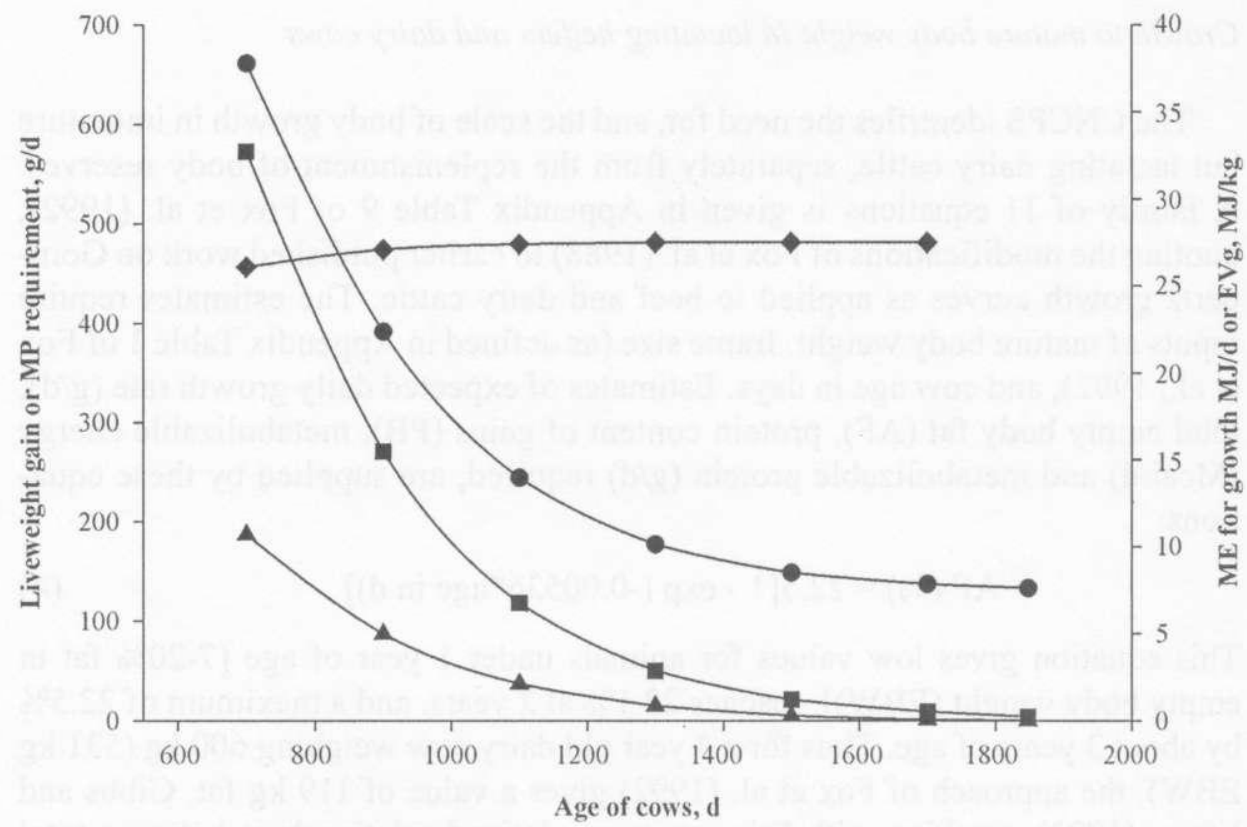

Figure 1. Growth requirements of lactating heifers and cows to five years of age. Symbols: liveweight gain; (•) ME for growth; $(\boldsymbol{\Delta}) \mathrm{MP}$ for growth; $(\bullet) \mathrm{EVg}$

As a result the ME required starts at a high value of $37 \mathrm{MJ} \mathrm{ME} / \mathrm{d}$ at 2 years old, falling steeply to only $3 \mathrm{MJ} / \mathrm{d}$ at 3 years. The high energy requirement for growth predicted for a two year old heifer ( $40 \%$ of normal maintenance requirements) is questionable. The energy value of these gains can be calculated to start at $26.1 \mathrm{MJ} /$ $\mathrm{kg}$ for a 2 year old heifer. As the protein content of the gain is also predicted, then using energy values for protein and fat of 23.6 and $39.3 \mathrm{MJ} / \mathrm{kg}$ respectively, it can be calculated that these gains must contain $55 \%$ fat. At 4 years of age, predicted energy value of the gains has only increased slightly to $27.5 \mathrm{MJ} / \mathrm{kg}$, implying $60 \%$ fat in the gains. The predicted high energy values (and associated high fat contents of the gains) probably arise from using the NRC (1984) prediction equations outside the range of the original data set.

Adjustments for liveweight change in lactating dairy cows

The CNCPS supplies no estimates of rates of liveweight loss in cows in early lactation, or their equivalence in energy terms, but prefers to use condition score (1-5) as an estimator of changes in body energy, claiming that this is a more reliable estimator than liveweight, adopted in ARC (1980) and NRC (1988). The equa- 
tions use condition score and use as a base the percentage of empty body fat $[\mathrm{AF} \%$, see equation (4)].

The proportion of the body fat that can be mobilized (RF\%) as a function of condition score is given by Fox et al. (1992) as:

Mobilizable empty body fat, $\mathrm{RF} \%=5+(0.25 * \mathrm{AF} \%-1.25) * \mathrm{CS}-1)$

which for a mature $600 \mathrm{~kg}$ cow at $\mathrm{CS}=3$ gives $13.8 \%$ of total body fat $(16.4 \mathrm{~kg}$ fat $)$ and varies from $5 \%(6 \mathrm{~kg})$ to $22.5 \%(27 \mathrm{~kg})$ as CS varies $1-5$, which can be compared with Gibb et al. (1992) who found that $34 \%$ of total fat (c. $70 \mathrm{~kg}$ ) had been mobilized by week 8 of lactation.

The calculation of the energetic equivalent of one CS change by Fox et al. (1992) is from the mobilizable fractions of both fat (RF) and protein (BP), not the total body contents of fat and protein. The mean energy value of 1 CS change in dairy cattle is given as $400 \mathrm{Mcal}(1,674 \mathrm{MJ})$ by Ferguson and Otto (1989), quoted by Fox et al. (1992), but Table 2 of the latter paper gives values varying from 416 $(1,741 \mathrm{MJ}$ for $\mathrm{CS}=1)$ to $509 \mathrm{Mcal}(2,130 \mathrm{MJ}$ for $\mathrm{CS}=5)$, recognizing the higher energy value of mobilizable tissue in fat, high CS beef cows. The application of these derived relationships to high yielding Holstein cows was examined by Otto et al. (1991), who compared CS and determined body fat (9-11 rib tissue) in 50 Holstein cows. They reported an $18 \%$ over prediction of body fat, requiring a $1 \mathrm{CS}$ reduction ( $=70 \mathrm{Mcal}$ or $290 \mathrm{MJ}$ ) to get comparable figures, i.e. reducing the suggested range to 1,450-1,840 MJ per CS change, mean 1,645 MJ, similar to Gibbs and Ivings (1993) who found 1,615 MJ per CS change. The predictions obtained from these two sets of equations are compared in Figure 2.

The total body fat predictions agree for $\mathrm{CS}=3$, but the Gibb and Ivings (1993) values reach a maximum of $222 \mathrm{~kg}$ at $\mathrm{CS}=5$. The predicted total body protein content is likewise strikingly different between the two sets of equations. Gibb and Ivings (1993) found no effect of CS upon total body protein, which was found to be c. 0.10 of liveweight $(0.11$ of EBW) for Holstein-Friesian cows:

$$
\text { Protein }(\mathrm{kg})=0.0997 \mathrm{~W}+22.37
$$

The equations of Fox et al. (1992) predict per cent empty body protein (AV\%) as:

$$
\mathrm{AV} \%=0.7995(23.7-0.027 \mathrm{AF} \%)
$$

which gives $18.9 \%$ (98 kg emply body protcin) for a maximum total body fat of $22.5 \%$ in a cow of $600 \mathrm{~kg}$ liveweight (531 kg EBW), compared to $11 \%(60 \mathrm{~kg})$ from Gibb and Ivings (1993).

The protein content of the fat free empty body of cattle is accepted as reasonably constant and Garrett (1987) gave a value of $21.6 \%$ protein for beef cattle. Using the predicted total fat and protein contents of cow liveweight (calculated to EBW as ARC, 1980) from Gibb and Ivings (1993), values of $12.7-19.7 \%$ for the 


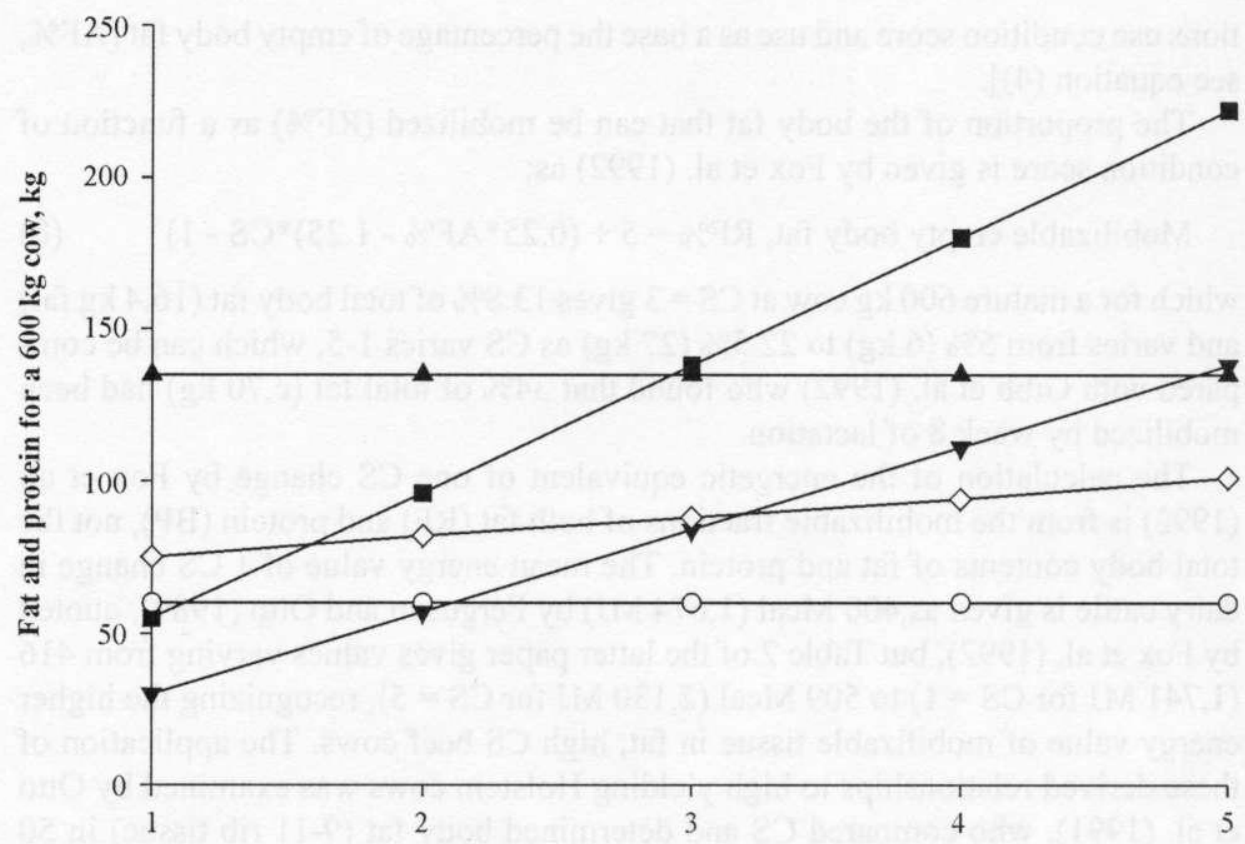

Condition score

Figure 2. Predicted body composition of dairy cows as affected by condition score. Symbols: (耳) fat as Gibb and Ivings (1993); (O) protein as Gibb and Ivings (1993); ( $\mathbf{\Delta})$ AF (maximum total body fat) as Fox et al. (1992); ( $\mathbf{\nabla})$ RF (mobilizable empty body fat) as Fox et al. (1992); ( 0 ) BR (available body protein adjusted for CS) as Fox et al. (1992)

protein content of fat free empty body weight as CS varied 1-5 are obtained. The value for $\mathrm{CS}=4(17.3 \%)$ is in reasonable agreement with Fox et al. (1992), but all values are below the estimate of Garrett (1987).

NRC (1988) assigns an average value of $6 \mathrm{Mcal}$ (=25.1 MJ) of net energy per $\mathrm{kg}$ liveweight change in lactating dairy cattle. AFRC (1993) adopted $19.0 \mathrm{MJ} / \mathrm{kg}$ liveweight change (based on Gibb et al., 1992) and assumes a liveweight loss of $0.5 \mathrm{~kg} / \mathrm{d}$ as typical for cows in the first 10 weeks of lactation. Over a 10 week period in early lactation, the loss of $0.5 \mathrm{CS}$ would be equivalent to about $12 \mathrm{MJ}$ net energy/d according to the CNCPS, equivalent to $0.63 \mathrm{~kg} / \mathrm{d}$ liveweight loss according to AFRC (1993), or $0.48 \mathrm{~kg} / \mathrm{d}$ according to NRC (1988).

There appears to be no mention in Fox et al. (1992) of the contribution of mobilized body protein to milk synthesis, nor of its efficiency of utilization. A term for it does not appear in the summative equation quoted for total MP requirements, only a term for growth. NRC (1985), p.71 states that $1 \mathrm{~kg}$ empty body gain supplies the equivalent of $160 \mathrm{~g}$ available protein (AP) and this is utilized 
with an efficiency of 1.0. However, NRC (1988) states that the crude protein in $1 \mathrm{~kg}$ EBW loss is $320 \mathrm{~g}$, equivalent to $256 \mathrm{~g} \mathrm{AP}$, similar to AFRC (1992), which has $233 \mathrm{~g} \mathrm{MP} / \mathrm{kg}$, assuming an efficiency of mobilization of 1.0 .

\section{Definition of effective NDF in defining minimum dietary fibre requirements}

Effective NDF (eNDF) was defined by Mertens (1985) on the basis of measurements of the particle size of feeds (by dry sieving feeds through a $1.18 \mathrm{~mm}$ screen) to determine the proportion of NDF that had larger particle size than $1.18 \mathrm{~mm}$. This was used as an estimate of the effect of both the amount and form of fibre present in a feed upon chewing time, rumen structure, rate of fermentation in the rumen, rumen $\mathrm{pH}$ and rate of escape of solid feed particles. The parameter is included in Tables 2 and 3 of Sniffen et al. (1992), listing passage rates of concentrates and forage. Values for eNDF\% (as \% of NDF) are given for low NDF feeds such as ground wheat and soyabean meal. Unfortunately, the situation is confused by the use of the term RFNDF in the glossary found in Russell et al. (1992), where it is defined as "\% of NDF dry matter that is forage NDF", which can have similar dimensions to diet eNDF\% in DM. The term RFNDF appears as a correction (if RFNDF $<20$ ) in the equation for maximum microbial yield $\mathrm{YG1:}$

$$
\mathrm{YGl}=\mathrm{YG}-0.025(\mathrm{RNDF} \%-20)
$$

NRC (1996) has eNDF in the otherwise identical equation, as do both the computer models examined, so the term RFNDF appears subsequently to have been dropped. Its description as "forage NDF" would exclude the NDF in the concentrate portion of a diet completely, in contradiction to the tabulated eNDF\% of NDF values for concentrates given by Sniffen et al. (1992), Tables 4-6. However, both versions of the software examined and that published in NRC (1996) have diet eNDF as \% in dry matter as the parameter driving the YG1 equation.

The parameter eNDF\% in diet DM is also used in the model to predict rumen $\mathrm{pH}$ and changes in a number of microbial yicld parameters, rates of $\mathrm{CHO}$ degradation and VFA production, as reviewed in Alderman et al. (2001a).

Prediction of NDF requirement is given in Fox et al. (1992), p. 3,587, where Williams (1988) is quoted as having indicated that the NDF capacity of dairy cows was given by:

NDFPBW (as \% body weight $)=0.8+0.4(\mathrm{DOL} / 100)$

where

DOL is day of lactation,

NDFPBW is NDF per cent of body weight and has a maximum of $1.2 \%$.

It is not clear whether Williams (1988) was working with NDF or eNDF, hence the use of the words "based on" in Fox et al. (1992). The text of Fox et al. (1992), 
p. 3,587, twice states that the equation is predicting the need for effective NDF, although the acronym NDFPBW (NDF percent of body weight) is used in the published equation, not eNDF. Equation (12) gives 0.8 and $1.2 \%$ of body weight at calving and $100 \mathrm{~d}$ post partum, respectively. Thus the NDF requirement of a $600 \mathrm{~kg}$ cow in early lactation is predicted to be $6 \mathrm{~kg}$, the equivalent of about $30 \%$ NDF in diet DM. If the equation is predicting NDF requirements, not eNDF, then for typical dairy cow diets, where eNDF as \% of NDF is $65-70 \%$, then the eNDF requirement drops to $21 \%$ of diet DM. This agrees well with p. 3,588, para. 2 of Fox et al. (1992), which has the statement "effective NDF is normally taken as $20 \%$ of diet dry matter for lactating dairy cows". However, minimum eNDF\% to maintain normal rumen $\mathrm{pH}$ and microbial protein synthesis is set at $26.5 \%$ by the companion paper Russell et al. (1992), which is lower than the result of using equation (12).

\section{Prediction of milk yield}

Expected milk yield is predicted by an equation (units not stated, presumed to be $\mathrm{kg} / \mathrm{d}$ ) based on Oltenacu et al. (1981), Marsh et al. (1988) and on the Wood (1967) equation coefficients: $a, b$ and $c$. The equation as published in Fox et al. (1992), p. 3,582 has the '^' sign missing in front of the coefficient $b$ and the coefficient $\mathrm{g}$ of Oltenacu et al. (1981) is listed wrongly as $\mathrm{d}$ in Table 1, which gives the coefficients of the Wood (1967) equation. Oltenacu et al. (1981) derived g to correct for the effects of pregnancy on daily milk yield and persistency. When corrected the equation becomes:

$$
\mathrm{MM}=\left(\mathrm{a}^{*} \mathrm{DOL}\right)^{\mathrm{b}} \mathrm{e}^{\mathrm{c} * \mathrm{DOL}} \mathrm{e}^{\mathrm{e}^{*} \mathrm{TGEST}}
$$

where

$\mathrm{MM}$ is milk yield in $\mathrm{kg} / \mathrm{d}$,

DOL is day of lactation,

TGEST is day of gestation.

The coefficient a in equation (13) is predicted from equation (14) for multiparous cows, using the rolling herd lactation average (GNRHA), lb milk per year:

$$
a=(0.01 G N R H A+14) / 2.96
$$

Prediction of voluntary dry matter intake of lactating dairy cows

The CNCPS uses the equation of Milligan et al. (1981) to predict the DMI of lactating dairy cattle:

DMI $(\mathrm{kg} / \mathrm{d})=[0.0185 \mathrm{BW}+0.305 \mathrm{MM}(0.4+0.15 \mathrm{PQ})]^{*} \mathrm{TEMP} 1 * \mathrm{MUD} 1$ 
where

$\mathrm{BW}$ is shrunk $(=0.96 \mathrm{~W})$ live body weight in $\mathrm{kg}$,

PQ is milk fat \%,

TEMPI is temperature adjustment as specified in Appendix, Table 4,

MUD1 is the mud adjustment factor as specified in Appendix, Table 4.

For UK conditions, TEMPI would be 1.03 for $5-15 \mathrm{EC}$ and MUD1 $=1.0$. For $4 \%$ butterfat, equation (15) simplifies to:

$$
\mathrm{DMI}=0.0178 \mathrm{~W}+0.305 \mathrm{MM}
$$

which can be compared with MAFF (1975):

$$
\mathrm{DMI}=0.025 \mathrm{~W}+0.1 \mathrm{MM}
$$

and ARC (1980) for mid-lactation:

$$
\mathrm{DMI}=0.135 \mathrm{~W}^{0.75}+0.2 \mathrm{MM}-3.2
$$

NRC (1988) give a Table 6.1 for the voluntary DMl of dairy cows, varying with body weight and milk yield, expressed as percent of body weight, which is compared with the CNCPS equation in Figure 2 of Fox et al. (1992). When compared with observed DMI, the NRC and CNCPS equations had low $\mathrm{r}^{2}$ values, 0.43 and 0.49 , biases of $-5 \%$ and $+6 \%$ and standard errors of estimate of \pm 1.5 and $\pm 1.7 \mathrm{~kg} / \mathrm{d}$. AFRC (1991) recommended the equation of Vadiveloo and Holmes (1979), which takes account of the week of lactation $(\mathrm{n})$ and amounts of concentrate $(\mathrm{C}, \mathrm{kg} / \mathrm{d})$ fed:

$$
\mathrm{DMI}=0.076+0.404 \mathrm{C}+0.013 \mathrm{~W}-0.129 \mathrm{n}+4.12 \log _{10}(\mathrm{n})+0.14 \mathrm{MM}
$$

If it assumed that concentrates will be fed at $0.4 \mathrm{~kg} / \mathrm{kg}$ milk above the contribution from the forage component of the diet, then at week 16 of lactation, equation (19) gives very similar results to CNCPS v.3.0 and NRC (1988), as shown in Figure 3.

It is clear that the equations of MAFF (1975) and ARC (1980), for milk yields above $40 \mathrm{~kg} / \mathrm{d}$, give estimates which are low by more than $5 \mathrm{~kg}$ of DMI, compared to either CNCPS or NRC (1988). None of these equations takes account of the effects of forage quality upon voluntary intake.

The logarithmic function in the Vadiveloo and Holmes (1979) equation also predicts reduced DMI in early lactation, which is well recognised. CNCPS v.3.0 includes an exponential function to give a lag factor $(l)$ to adjust for depressed DMI in early lactation (true DMI calculated as / times predicted DMI):

$$
l=1-\exp [-0.549(\mathrm{DOL}+2.36)]
$$

where

DOL is days in milk expressed in units of a week. 


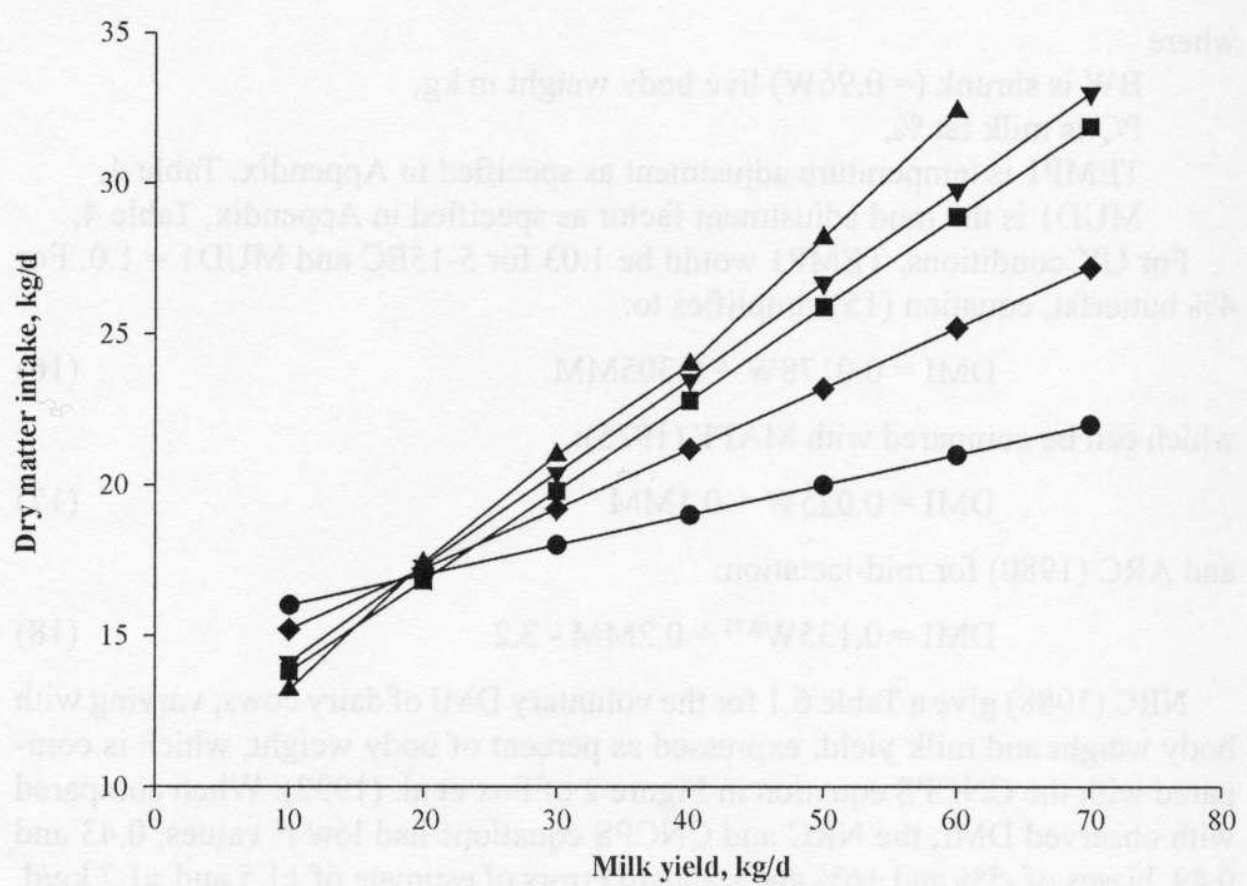

Figure 3. Prediction of dry matter appetite of lactating dairy cows. Symbols:( $)$ CNCPS v.3.0; MAFF (1975); ( ARC (1980); ( $\mathbf{\Delta})$ NRC (1988); () AFRC (1991)

At week 1, equation (20) gives a lag factor of 0.84 , which for a DMI of $18 \mathrm{~kg} / \mathrm{d}$ is a reduction of $2.9 \mathrm{~kg} / \mathrm{d}, 0.91$ at week $2(1.6 \mathrm{~kg} / \mathrm{d})$ and 1.0 at week 8 . The Vadiveloo and Holmes (1979) equation also gives a factor of 0.84 at week 1 and maximum DMI occurring at weeks 9-10 of lactation.

\section{Pregnancy requirements}

Energy. Net energy requirements for gestation in the CNCPS v.3.0 were based on modifications of the set of 23 equations of Fox et al. (1988) for the net energy and net protein content of the foetus, cotyledon, placenta, uterus and foetal fluid, listed in Appendix Table 12 of Fox et al. (1992). These individual requirements are summed to give the total foetus net energy (FNE) as kcal/d:

$$
\mathrm{FNE}(\mathrm{FE})=\mathrm{FE}+\mathrm{CE}+\mathrm{NE}+\mathrm{UE}+6.877
$$

where

FE is foetal energy,

$\mathrm{CE}$ cotyledon energy, 
NE placental energy,

UE uterus energy.

This equation as published in Fox et al. (1992), Appendix Table 12 lists the term FE twice with two different definitions in the footnote. Above, the summation term FE has been replaced with FNE, foetal net energy, for clarity. Note also the unexplained constant term, 6.877. CNCPS v.3.0 replaced this original set of 23 equations with the estimates of Bell et al. (1992). The latter simplified them to an allowance of $0.228 \mathrm{Mcal} \mathrm{NEL} / \mathrm{d}(1.54 \mathrm{MJ} \mathrm{ME} / \mathrm{d})$ for less than 180 days pregnant with a standard $45 \mathrm{~kg}$ calf, other calf weights being linearly scaled. After 180 days, the requirement is set at $3.46 \mathrm{Mcal} \mathrm{NEL} / \mathrm{d}(23.3 \mathrm{MJ} \mathrm{ME} / \mathrm{d})$.

\section{AMINO ACID REQUIREMENT MODEL}

The amino acid (AA) sub-model of the CNCPS predicts the supply of, and the requirement for, absorbed amino acids. The basis is the prediction of MP supply and animal MP requirement described in Fox et al. (1992). The prediction of potential AA deficiencies (methionine and lysine particularly) depends more on the assumed efficiencies of utilization of AA than assumptions as to the AA composition of rumen bacteria (including protozoa), undegraded feed protein and the AA composition of the animal products.

\section{Amino acid requirements}

AA requirements are calculated as the product of the net protein requirements for scurf, metabolic faecal, body and milk protein, the AA composition of the products formed, divided by the efficiency with which the individual AA is utilized for protein synthesis.

AA composition of tissue, milk, keratin and endogenous urinary losses. Table 3 of O'Connor et al. (1993) gives the AA composition values for tissues and products adopted for use in the CNCPS, including keratin. Those for tissue and milk are compared with those quoted by Oldham (1987) in Table 1.

Both data scts are in good agreement and predict a potential deficiency of histidine for milk synthesis, since the histidine content of rumen bacteria is only $0.6-$ 0.75 of that in milk, but neither indicate the likelihood of deficiencies of methionine and lysine found in non-ruminants. In the CNCPS, keratin is taken as typical of the hair and scurf protein component of maintenance. It has a much lower content of methionine, lysine and a higher level of threonine than milk or tissue. Urinary $\mathrm{N}$ (EUN) is probably only a partial AA expense, but in the CNCPS the AA content of tissue is used to determine the net AA requirement implied by EUN. 
TABLE 1 Amino acid composition (\% in DM) of tissues and rumen bacteria in the CNCPS compared with those given by Oldham (1987)

\begin{tabular}{|c|c|c|c|c|c|c|}
\hline \multirow[b]{2}{*}{ Amino acid } & \multicolumn{2}{|c|}{ Tissue } & \multicolumn{2}{|c|}{ Milk } & \multicolumn{2}{|c|}{ Rumen bacteria } \\
\hline & $\begin{array}{c}\text { Oldham } \\
\text { (1987) }\end{array}$ & CNCPS & $\begin{array}{c}\text { Oldham } \\
\text { (1987) }\end{array}$ & CNCPS & $\begin{array}{c}\text { Oldham } \\
(1987)\end{array}$ & CNCPS \\
\hline Leucine & 7.2 & 6.7 & 8.9 & 9.2 & 7.6 & 8.1 \\
\hline Isoleucine & 3.0 & 2.8 & 5.2 & 5.8 & 5.6 & 5.7 \\
\hline Valine & 4.2 & 4.0 & 6.1 & 5.9 & 5.2 & 6.2 \\
\hline Threonine & 4.2 & 3.9 & 4.2 & 3.7 & 5.2 & 5.8 \\
\hline Lysine & 6.8 & 6.4 & 7.1 & 7.6 & 8.4 & 7.9 \\
\hline Tryptophan & 0.8 & 0.6 & 1.4 & 1.5 & 1.5 & ns \\
\hline Histidine & 2.7 & 2.5 & 2.4 & 2.7 & 1.4 & 2.0 \\
\hline Methionine & 1.9 & 2.0 & 2.4 & 2.7 & 2.6 & 2.6 \\
\hline Phenylalanine & 3.8 & 3.5 & 4.7 & 4.8 & 5.8 & 5.1 \\
\hline
\end{tabular}

ns not stated

Efficiencies of utilization of absorbed AA. Efficiencies of utilization for maintenance and gestation of 0.85 for all AA were originally adopted in the CNCPS, except for leucine, iso-leucine and valine, where a value of 0.66 was taken for maintenance and arginine was included at 0.66 for gestation. For milk, the values of Evans and Patterson (1985) varying from 0.83-1.00 (methionine 0.98 and lysine 0.88 ) are also adopted, with the exception of leucine, iso-leucine, valine and arginine, where the lower values $(0.72,0.62,0.72$ and 0.42$)$ suggested by Oldham (1980) are adopted.

\section{Amino acid balance}

Metabolizable protein supplies both essential and non-essential AA, but the vital comparison is of the supply of, and requirement for the essential AA, such as lysine and methionine. Hanigan et al. (1997) have pointed out that the approach used in the CNCPS ignores any possibility of the metabolism (de-amination) of AA as a source of glucose, common in cows in negative energy balance in early lactation, or of any transformation of AA in the intestinal wall or liver.

\section{DEVELOPMENT OF THE CNCPS MODEL SINCE 1992}

Since its publication in 1992 as a series of papers in the Journal of Animal Science, the CNCPS as applied to beef cattle has been adopted in the NRC (1996) publication Nutrient Requirements of Beef Cattle. The latter publication has been 
used as a cross check on the core rumen equations, which revealed some subsequent modification and updating of the model. In particular, changes appear to have been made to the efficiencies of AA utilization adopted. However, the CPM Dairy version of the CNCPS has also modified significantly a number of components of the CNCPS requirement sub-model, detailed below.

\section{Energy}

Maintenance. The energy requirements for maintenance have reverted to the NRC (1988) single estimate of $0.556 \mathrm{MJ} / \mathrm{kgW}^{0.75}$ for all breeds and crosses of dairy cow, by dropping the factor 1.2 for all breeds and cross brceds other than Holstein pure bred cows. This reduces the ME requirement of most $600 \mathrm{~kg}$ dairy cows, other than pure bred Holsteins, by about $12 \mathrm{MJ} / \mathrm{d}$, and consequently raises the predicted milk yield by more than $2 \mathrm{~kg}$ milk/d. The environmental model adjusting maintenance energy has also been modified, but for housed dairy cattle, these are of little consequence, except in extremes of temperature.

Total Digestible Nutrients. The alteration to the coefficient for fat in the calculation of TDN content of feeds and diets introduced in CPM Dairy, reviewed in Alderman et al. (200 lb), was based on the more efficient use of fat for milk and tissue synthesis found by Andrews et al. (1991). The consequence is a hidden increase in the realised efficiency of utilization of $\mathrm{ME}$ for milk, since the conversions of TDN values to DE, ME and NEL given by NRC (1988) were obtained using bTDN\% values derived by using the classical formula with an oil factor of 2.25. This type of empirical correction obscures the proper separation of feed energy values from efficiency of energy utilization and the net energy requirements of the target animals as originally laid down by Blaxter (1962) in his three compartment model adopted in the ARC (1965) metabolizable energy model. He claimed "The new scheme avoids the muddling of the efficiency of the animal with the nutritive value ascribed to the feed'. Experience of the ME system used in the UK has borne out the utility of this principle when inserting new net energy data on body composition or modifying efficiency factors. Net energy values of tissues, products and requirements are true net energies, not adjusted values as in the NEL systems of NRC (1988) and INRA (1988).

Liveweight change adjustments. Liveweight change has been restored as an indicator of cnergy and protein balance in lactating dairy cows, in line with the recommendations of NRC (1988), instead of relying only on condition score as in CNCPS v.3.0. The relevant energy and protein correction factors for liveweight change in lactating dairy cows were reviewed earlier in this paper.

Pregnancy. The version of the CNCPS incorporated in CPM Dairy specifies that the pregnancy energy requirements $\left(\mathrm{NE}_{\mathrm{m}}\right)$ are calculated according to $\mathrm{NRC}$ (1996) for beef cattle up to 190 days pregnant, thereafter the estimates of Bell et al. 
(1995) are adopted. However, the CPM Dairy equation listing supplied to the author reveals a large difference in one of the coefficients in the quoted NRC (1996) model for less than 190 days of pregnancy. NRC (1996) has:

$$
\mathrm{NE}_{\mathrm{m}}(\mathrm{Mcal} / \mathrm{d})=\mathrm{CBW}^{*}(\underline{0.4504}-0.0000996 \mathrm{t}) * \exp [(0.0323-0.0000275 \mathrm{t}) * \mathrm{t}]
$$

where

CBW is calf birth weight in $\mathrm{kg}$,

$t$ is days pregnant.

whereas CPM Dairy has:

$$
\mathrm{NE}_{\mathrm{m}}(\mathrm{Mcal} / \mathrm{d})=\mathrm{CBW}^{*}(0.05855-0.0000996 \mathrm{t})^{*} \exp \left[(0.0323-0.0000275 \mathrm{t})^{*} \mathrm{t}\right]
$$

Equation (22) gives unrealistically high $\mathrm{NE}_{\mathrm{m}}$ values, 10 times those of equation (23), so there appears to be a typographical error in the constant 0.4504 , as all other terms are identical. Equation (23) gives sensible values by comparison with those from AFRC (1993). The estimates of Bell et al. (1995) for late pregnancy energy requirements ( $>190$ days) are only given as tabulated values, stated to be derived by differentiating the quadratic equations for the accumulated net energy in the gravid uterus, but the relevant linear equation with respect to $t$ was not quoted:

$$
\mathrm{NE}_{\mathrm{rm}}(\mathrm{Mcal} / \mathrm{d})=(\mathrm{CBW} / 45) *(0.0031 \mathrm{t}-0.0352)
$$

The correctly derived equation (24) appears in the CPM Dairy equation listing, revealing that the Table $2 \mathrm{NE}_{\mathrm{m}}$ values of Bell et al. (1995) are consistent to $37 \mathrm{kcal} / \mathrm{d}$ $(0.16 \mathrm{MJ} / \mathrm{d})$, or 0.95 of the correctly derived values. This would not appear to be due to correction for calf birth weight, which was $46 \mathrm{~kg}$, above the normal mean of $45 \mathrm{~kg}$ for Holstein cows, because this would have raised the calculated value of $\mathrm{NE}_{\mathrm{in}}$.

The calculated $\mathrm{ME}$ requirements rely on an efficiency of $\mathrm{ME}$ utilization factor $\left(\mathrm{k}_{\mathrm{c}}\right)$ which varies in the various models from 0.125 (CNCPS v.3.0) to 0.13 [NRC (1996) and CPM Dairy], to 0.133 (AFRC, 1993). The pregnancy energy requirements for a standard $45 \mathrm{~kg}$ calf birth weight generated by equations (23) and (24), the tabulated values of Bell et al. (1995), converted to MJ of ME by using $\mathrm{k}_{\mathrm{m}}=$ 0.72 and $k_{c}=0.13$, and those from equations (70) and (71) of AFRC (1993) are compared in Figure 4.

The discontinuity in ME requirements given by the two CPM Dairy equations at 190 days is disconcerting, but over the range 150-230 days of pregnancy, there is reasonable agreement between them and the AFRC (1993) ME requirements, widening to a two fold difference at term.

\section{Protein}

Relatively few changes have been made in the protein requirements model used in the CNCPS version incorporated in CPM Dairy. The net protein requirements 


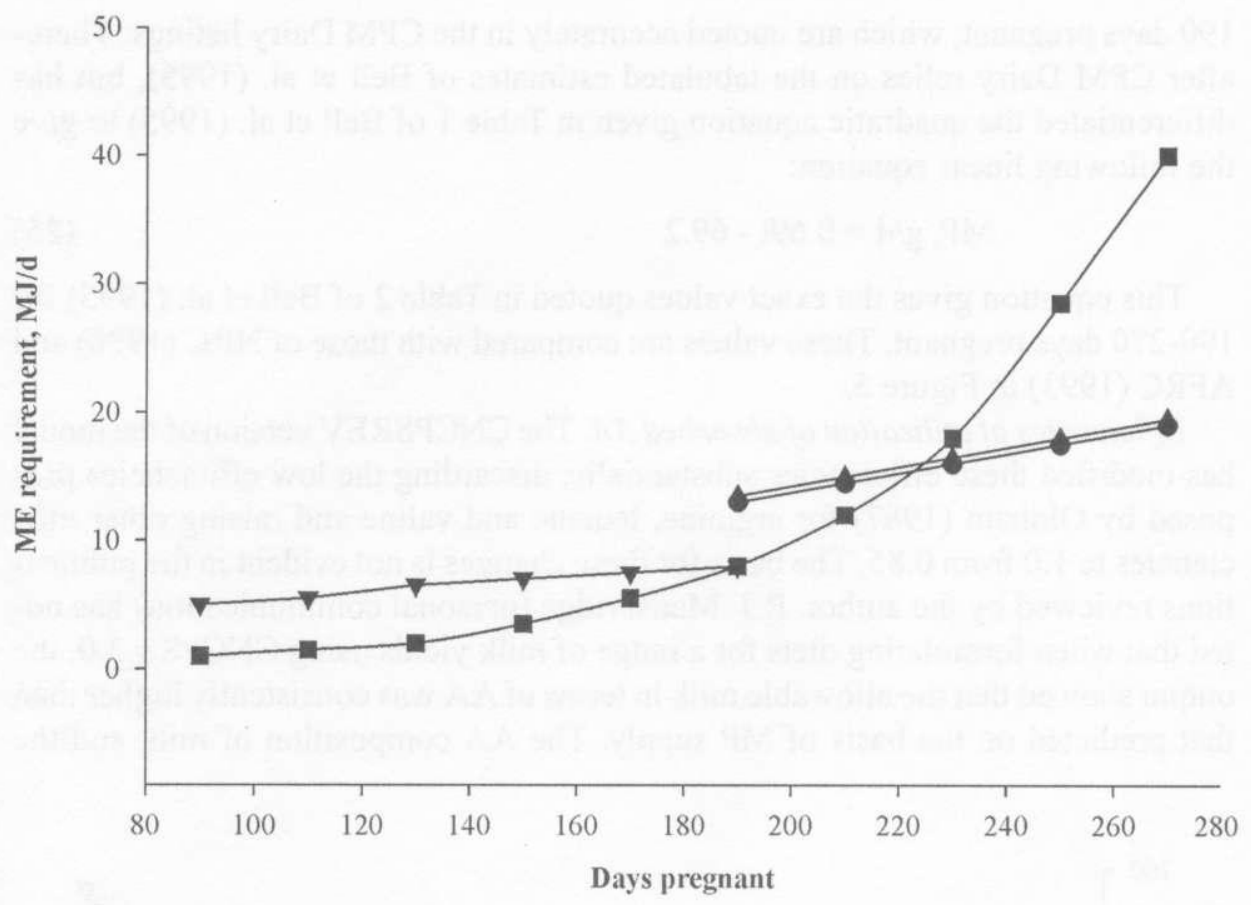

Figure 4. Metabolizable energy requirements for pregnancy compared. Symbols: ( $\boldsymbol{\nabla})$ CPM Dairy (<190 d); (4) CPM Dairy (>190 d); ( Bell et al. (1995); (푸) AFRC (1993)

and efficiency of utilization factors are still mostly as NRC (1985). The exceptions are discussed below.

Body composition. Some changes have been made recently to the estimates of changes in body composition, but these modifications are not covered in this review.

Pregnancy. CNCPS v.3.0 replaced the Fox et al. (1992) set of 23 equations for available protein requirements for pregnancy with the estimates of Bell et al. (1992), who simplified them to an allowance of $14 \mathrm{~g} \mathrm{AP} / \mathrm{d}$ for less than 180 days pregnant with a standard $45 \mathrm{~kg}$ calf, other calf weights being scaled linearly. After 180 days, the requirement is $180 \mathrm{~g} \mathrm{AP} / \mathrm{d}$. Average daily gain due to pregnancy is estimated to be $100 \mathrm{~g} / \mathrm{d}$ for less than 180 days pregnant and $665 \mathrm{~g} / \mathrm{d}$ thereafter. Such large jumps in $\mathrm{AP}$ requirement as the cow passes 180 days pregnant are a poor substitute for an appropriate growth function, such as the Gompertz adopted in ARC (1980). The latter calculates net protein requirements well below those of NRC (1988) and the CNCPS in early pregnancy, when requirements are small. The CPM Dairy version of the CNCPS now uses the equations for beef cattle given in NRC (1996) up to 
190 days pregnant, which are quoted accurately in the CPM Dairy listings. Thereafter CPM Dairy relies on the tabulated estimates of Bell et al. (1995), but has differentiated the quadratic equation given in Table 1 of Bell et al. (1995) to give the following linear equation:

$$
\text { MP, g/d }=0.69 \mathrm{t}-69.2
$$

This equation gives the exact values quoted in Table 2 of Bell et al. (1995) for 190-270 days pregnant. These values are compared with those of NRC (1996) and AFRC (1993) in Figure 5.

Efficiencies of utilization of absorbed AA. The CNCPSREV version of the model has modified these efficiencies substantially, discarding the low efficiencies proposed by Oldham (1987) for arginine, leucine and valine and raising other efficiencies to 1.0 from 0.85 . The basis for these changes is not evident in the publications reviewed by the author. R.J. Mansbridge (personal communication) has noted that when formulating diets for a range of milk yields using CNCPS v.3.0, the output showed that the allowable milk in terms of AA was consistently higher than that predicted on the basis of MP supply. The AA composition of milk and the

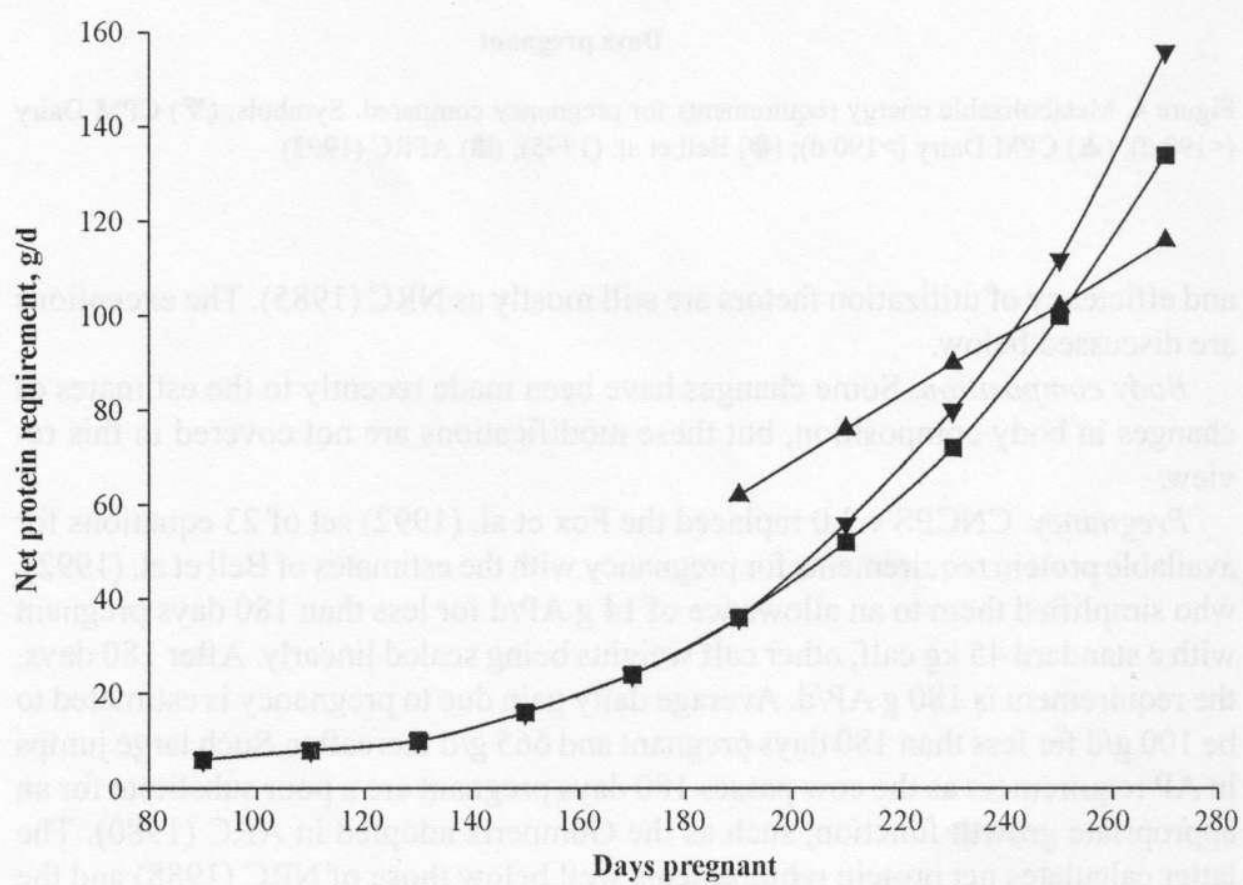

Figure 5. Net protein requirements for pregnancy compared. Symbols: ( $\mathbf{\nabla})$ NRC (1996); ( $\mathbf{\Delta})$ Bell et

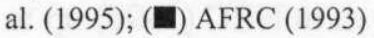


efficiencies of essential AA (EAA) utilization for milk synthesis given in O'Connor et al. (1993) were used to calculate a weighted mean efficiency of utilization, assuming that non-essential AA would be used with the default efficiency of 0.85 , in the absence of any statement to the contrary. The weighted mean efficiency of utilization of EAA for milk synthesis was found to be 0.78 . The remainder of the milk protein, corrected for $50 \mathrm{~g} / \mathrm{kg}$ non-protein nitrogen, was synthesised with an efficiency of 0.85 , to give an overall weighted mean of 0.81 . This can be compared with NRC (1985) which gave a figure of 0.65 and NRC (1988) which has 0.70 . As CNCPS v.3.0 uses the NRC (1985) figure of 0.65, this implies that AA allowable milk (assuming no limiting EAA) would be $0.78 / 0.65=1.25$ or $25 \%$ higher than that calculated from MP supply. The mean increase observed by R.J. Mansbridge for milk yields varying $25-55 \mathrm{~kg} / \mathrm{d}$ was $23 \%$, varying $12-31 \%$, in good agreement with the above calculations. The efficiencies adopted in CNCPSREV are even higher, since the low values of Oldham (1987) for leucine, isoleucine, valine and arginine have also been dropped. The weighted mean efficiency for CNCPSREV was found to be $0.88,35 \%$ higher than NRC (1985) and $26 \%$ higher than NRC (1988). Clearly more work on the efficiencies of utilization of individual EAA and non-essential AA is required.

Rulquin and Verite (1993) have suggested that the response to EAA such as lysine and methionine for dairy cows is curvilinear, expressed as milk protein response $(\mathrm{g} / \mathrm{d})$ to $\% \mathrm{AA}$ in the PDI (viz. protein digested in the intestine) supplied, so that a fixed efficiency of utilization may be inappropriate. The CPM Dairy version of CNCPS has adopted the approach of Rulquin and Verite (1993) in adjusting predictions of allowable milk based on AA supply and balance. The lack of other recent experimental determinations of the efficiencies of utilization of AA mean that this is the weakest part of this AA model, since the predictions coming from it depend crucially upon these values as Hanigan et al. (1997) have pointed out.

\section{Physically effective NDF (peNDF)}

Following the publication of Mertens (1997), which reviewed, revised and reestimated effective NDF values (eNDF), renaming the new values 'physically effective NDF' (peNDF), these tabulated values have been adopted in the feed composition tables of the CPM Dairy version of the CNCPS. Across a range of US dairy cow diets, the mean dietary peNDF\% was found to average about $3 \%$ units higher than the old eNDF values (W. Chalupa, personal communication) which this author has confirmed for the $18 \mathrm{UK}$ dairy herd diets used in the study of the CNCPS by Mansbridge et al. (1999). Consequently, the target peNDF\% for dairy cow diets has been adjusted upwards, i.e. from 20 to $23 \%$ as the minimum value for cows in early lactation. 


\section{ACKNOWLEDGEMENTS}

The author gratefully acknowledges much valuable help and criticism of this manuscript from a number of people during its preparation, and also the supply of relevant reprints and manuscripts of papers in press. Dr D. G. Fox of Cornell University supplied an open version of the then (1997) current CNCPS computer model, whilst Dr W. Chalupa of Pennsylvania University supplied an equation listing for CPM Dairy and additional comments. Dr J. Dijkstra of Wageningen University contributed comments on the mathematical modelling aspects of the CNCPS. Funding for this work was provided by the MAFF LINK Project Feed into Milk, which is gratefully acknowledged.

\section{REFERENCES}

AFRC, 1991. Voluntary Intake of Cattle. Technical Committee on Responses to Nutrients, Report No. 8. Nutr. Abs. Rev., Ser. B 61, 815-823

AFRC, 1992. Nutritive Requirements of Ruminant Animals: Protein. Technical Committee on Responses to Nutrients, Report No. 9. Nutr. Abs. Rev., Ser. B 62, 787-835

AFRC, 1993. Energy and Protein Requirements of Ruminants. CAB International, Wallingford (UK) Alderman G., France J., Kebreab E., 2001a. A critique of the Comell Net Carbohydrate and Protein System with emphasis on dairy cattle. 1. The rumen model. J. Anim. Feed Sci. 10, 1-24

Alderman G., Blake J.S., France J., Kcbreab E., 2001b. A critique of the Cornell Net Carbohydrate and Protein System with emphasis on dairy cattle. 2. The post-rumen digestion model. J. Anim. Feed Sci. 10, 203-221

Andrews S.M., Tyrrell H.F., Reynolds C.K., Erdman R.A., 1991. Net energy for lactation of calcium salts of long-chain fatty acids for cows fed silage-based dicts. J. Dairy Sci. 74, 2588-2600

ARC, 1965. The Nutrient Requirements of Farm Livestock, No. 2, Ruminants. HMSO, London (UK)

ARC, 1980. The Nutrient Requirements of Ruminant Livestock. Technical Review by an Agricultural Research Council Working Party. Commonwealth Agricultural Bureau, Farnham Royal (UK)

ARC, 1984. The Nutrient Requirements of Ruminant Livestock, Supplement No.1. Report of the Protein Group of the ARC Working Party. Commonwealth Agricultural Burcau, Farnham Royal, (UK)

Bell A.W., Rymph M.B., Slepetis R., House W.A., Ehrhardt R.A.,1992. Net nutrient requirements for conceptus growth in Holstein cows-implications for dry cow feeding. Proceedings of Cornell Nutrition Conference, Cornell University, lthaca, NY (USA), p. 102

Bell A.W., Slepetis R., Erhardt R.A., 1995. Growth and accretion of energy and protein in the gravid uterus during late pregnancy in Holstein cows. J. Dairy Sci. 78, 1954-1961

Blaxter K.L, 1962. The Energy Metabolism of Farm Animals. Hutchinson, London (UK)

Evans E.H., Patterson, R.J., 1985. Use of dynamic modelling seen as a good way to formulate crude protein, amino acid requirements for cattle diets. Feedstuffs 57,24

Ferguson J.D., Otto K.A., 1989. Managing body condition in cows. Proceedings of Cornell Nutrition Conference, Comell University, lthaca, NY (USA) 
Fox D.G., Sniffen C.J., O'Connor J.D., 1988. Adjusting nutrient requirements of beef cattle for animal and environmental variations. J. Anim. Sci. 66, 1475-1495

Fox D.G., Sniffen C.J., O'Connor Y.D., Russell J.B., Van Soest P.J., 1992. A net carbohydrate and protein system for evaluating cattle diets. III. Cattle requirements and dict adequacy. J. Anim. Sci. 70, 3578-3596

Garrett W.N., 1987. Relationship between energy metabolism and the amounts of protein and fat deposited in growing cattle. In: Energy Metabolism of Farm Animals. Proceedings of 10th Sympium, EAAP Publication No. 35, pp. 98-101

George P.D., 1984. A deterministic model of net nutrient requirements for the beef cow. Ph.D Thesis, Cornell University, lthaca, NY (USA)

Gibb M.J., lvings W.E., 1993. A note on the estimation of the body fat, protein and energy content of lactating Holstein-Friesian cows by measurement of condition score and liveweight. Anim. Prod. $56,281-283$

Gibb M.J., Ivings W.E., Dhanoa M.S., Sutton J.D., 1992. Changes in body components of autumncalving Holstein-Friesian cows over the first 29 weeks of lactation. Anim. Prod. 55, 339-360

Hanigan M.D., Dijkstra J., Gerrits W.J.J., France J., 1997. Modelling post-absorptive protein and amino acid metabolism in the ruminant. Proc. Nutr. Soc. 56, 631-643

INRA, 1988. Alimentation des Bovins, Ovins et Caprins. R. Jarrige (Editor). INRA, Paris (France)

Jones B.B., Kellaway R.C., Lcan I.J, 1996. Protein Requirements of Dairy Cows. University of Sydney, Dairy Research and Development Corporation, Glen Iris (Australia)

MAFF, 1975. Energy Allowances and Feeding Systems for Ruminants. MAFF Technical Bulletin 33. IMSO, London (UK)

Mansbridge R.J., Blake J.S., Bending l., 1999. A comparison of the prediction of intake and milk yield in high yielding dairy cows using either the UK rationing system or the Comell Net Carbohydrate and Protein System. Proceedings of BSAS Annual Meeting, p. 207

Marsh W.E., Galligan D.T., Chalupa W., 1988. Economics of recombinant bovine somatropin use in individual dairy herds. J. Dairy Sci. 71, 2944-2958

Mertens D.R., 1985. Effect of fiber on fecd quality for dairy cows. $48^{\text {th }}$ Minnesota Nutrition Conference, St Paul, MN, p. 209

Mertens D.R., 1997. Creating a system for meeting the fiber requirements of dairy cows. J. Dairy Sci. $80,1463-[48]$

Milligan R.A., Chase L.E., Sniffen C.J., Knoblauch W.A., 1981. Least-cost ration balanced dairy rations, a computer user's manual, Anim. Sci. Mimeo 54. Cornell University, Ithaca NY (USA)

Moe P.W., Flatt W.P., Tyrell H.F., 1972. The net energy of feeds for lactation. J. Dairy Sci. 55, 945958

NRC, 1978. Nutrient Requirements of Dairy Cattle. 5th revised Edition. US National Academy of Science, Washington, DC (USA)

NRC, 1984. Nutrient Requirements of Beef Cattle. 6th revised Edition. US National Academy of Science, Washington, DC (USA)

NRC, 1985. Ruminant Nitrogen Usage. US National Academy of Science, Washington, DC (USA)

NRC, 1988. Nutrient Requirements of Dairy Cattle. 6th revised Edition. US National Academy of Science, Washington, DC (USA)

NRC, 1996. Nutrient Requirements of Beef Cattle. 7th revised Edition. US National Academy of Science, Washington, DC (USA)

O’Connor J.D., Sniffen C.J., Fox D.G., Chalupa W., 1993. A net carbohydrate and protein system for evaluating cattle diets. IV. Predicting amino acid adequacy. J. Anim. Sci. 71, 1298-1311

Oldham J.D., 1980. Amino acid requirements for lactation in high yielding dairy cows. In: W. Haresign (Editor). Recent Advances in Animal Nutrition. Butterworths, London, pp. 33-65 
Oldham J.D., 1987. Efficiencies of amino acid utilisation. In: R. Jarrige, G. Alderman (Editors). Feed Evaluation and Protein Requirement Systems for Ruminants. CEC, Luxembourg, pp. 47-52

Oltenacu P.A., Rounsaville T.R., Milligan R.A., Foote R.H., 1981. Systems analysis for designing reproductive management programs to increase production and profits in dairy herds. J. Dairy Sci. 64, 2096-2104

Otto K.L, Ferguson J.D., Fox D.G., Sniffen C.J., 1991. Relationship between body condition score and composition of 9-11 rib tissue in Holstein dairy cows. J. Dairy Sci. 74, 852-859

Rulquin H., Verité R., 1993. Amino acid nutrition of ruminants. In: P.J. Garnsworthy, D.J.A. Cole (Editors). Recent Advances in Ruminant Nutrition. Nottingham University Press, Nottingham (UK), pp. 55-77

Russell J.B., O'Connor J.D., Fox D.G., Van Soest, P.J., Sniffen C.J., 1992. A net carbohydrate and protein system for evaluating cattle diets. I. Ruminant fermentation. J. Anim. Sci. 70, 35513561

Sniffen C.J., O'Connor J.D., Van Soest P.J., Fox D.G., Russell J.B., 1992. A net carbohydrate and protein system for evaluating cattle diets. II. Carbohydrate and protein availability. J. Anim. Sci. $70,3562-3577$

Vadiveloo J., Holmes W., 1979. The prediction of the voluntary intake of dairy cows. J. Agr. Sci. 93, 553-562

Williams C.B., 1988. Development of a Simulation Model to Provide Decision Support in Dairy Herd Nutritional Management. Ph.D Dissertation, Cornell University, Ithaca, NY (USA)

Wood P.D.P, 1967. Algebraic model of the lactation curve in cattle. Nature 216, 164-165

Yan T., Gordon F.J., Agnew R.E., Porter M.G., Patterson D.C., 1997. The metabolizable energy requirement for maintenance and the efficiency of utilisation of metabolizable energy for lactation by dairy cows offered grass silage-based diets. Livest. Prod. Sci. 51, 140-150

\section{STRESZCZENIE}

Krytyka „Cornell Net Carbohydrate and Protein System” ze szczególnym odniesieniem do bydla mlecznego. 3. Model zapotrzebowania

Cornell Net Carbohydrate and Protein System (CNCPS) wyraża zapotrzebowanie na energię w Mkal energii metabolicznej (ME), podobnie jak NRC (1988); odnosi się to do wartości ME pasz mierzonej przy bytowym poziomie żywienia. Jednakże, model ten wprowadza obliczone produkcyjne wartości ME do tych standardów NRC, a mianowicie równoważnik zwiększający poprawkę o około 5\% w stosunku do przyjętego oznaczonego zapotrzebowania na ME. Tak więc wyliczenie wartości energii według tego modelu jest wadliwe. Zapotrzebowanie bytowe wszystkich ras bydła mlecznego, innych niż holsztyńskie, jest powiększone przez mnożnik 1,2 na podstawie prac nad krowami-mamkami ras mięsnych. Współczynnik wykorzystania ME do syntezy mleka jest także zwiększony o stałą 0,65 , zamiast w normalnym przedziale od 0,62 do 0,64 , jak podano w NRC (1988). Ten efekt netto na przyjęte zapotrzebowanie ME przy wydajności mleka $30 \mathrm{~kg} / \mathrm{dzień} \mathrm{jest}$ mały, jednakże zarówno nachylenie jak i punkt przecięcia w równaniu jest inny niż w NRC (1988). Model nie uwzględnia wpływu ilości i składu dawki w podziale składników pokarmowych na produkcję mleka i ,potrzeby ciała”. Nie uwzględnia się w nim także wpływu składu dawki na przewidywany skład mleka, który jest albo daną wyjściową w modelu lub funkcją dnia laktacji. Skład ciała rosnących jałówek i krów do czwartego roku życia jest przewidywany na podstawie funkcji, w której 
maksymalna zawartość thuszczu w ciele wynosi $22,5 \%$, co stanowi tylko $86 \%$ całkowitej zawartości tłuszczu ciała oznaczonego ostatnio na podstawie pomiarów składu ciała mlecznych krów fryzyjskich. Związane z tym oszacowanic maksymalnej mobilizacji tjuszczu ciała jest o połowę lub nawet więcej niż o połowę poniżej wartości ostatnich pomiarów wykonanych na krowach mlecznych. W ,manipulowaniu” stratami energii i przyrostami w okresie laktacji przyjmuje się ocenę punktową jako miarę kondycji krów, a nie uwzględnia się masy ciała. Na podstawie wyników badań przeprowadzonych na krowach-mamkach ras mięsnych, stwierdzono przeszacowanje równoważnika energetycznego jednostki zınian w ocenie punktowej kondycji krów mlecznych rasy holsztyńskiej. Przewidywanie pobranja suchej masy jest bliższe rzeczywistemu niż inne przewidywania $z$ wykorzystaniem dostępnych zależności i nie uwzględnienie pobieranja paszy w okresie wczesnej laktacji, jest również dobrze dostosowane. Konsekwencją przyjęcia niewłaściwego zapotrzebowania na energię (jako $\mathrm{ME}$ ) jest to, że model przewiduje istotnie mniejszą produkcję mleka przy zerowym bilansie energii (bądź niższy bilans energii jeśli znana jest produkcja mleka) w porównaniu z NRC (1988) oraz AFRC (1983). Sprawdzenie modelu w doświadczeniu polowym wykazało jednakże, że przewidywana produkcja mleka jest bardzicj zbliżona do rzeczywistej niż przy wykorzystaniu innych modeli. 